\title{
IDENTIFYING FAKE NEWS: A LESSON FROM LIBRARY SCIENCE STUDENTS
}

\author{
Nora Saiva Jannana*, Thoriq Tri Prabowo**, \& Ratna Istriyani***
}

\begin{abstract}
*Islamic Education Management, Universitas Islam Negeri Sunan Kalijaga Yogyakarta
**Library and Information Science, Universitas Islam Negeri Sunan Kalijaga Yogyakarta

***Sociology of Religion, Universitas Islam Negeri Sunan Kalijaga Yogyakarta
\end{abstract}

Email: nora.jannana@uin-suka.ac.id, toriq.prabowo@uin-suka.ac.id,
ratna.istriyani@uin-suka.ac.id

(Submitted: 05-02-2021, Revised: 03-05-2021, Accepted: 03-06-2021)

DOI: $10.24252 / \mathrm{v} 9 \mathrm{i} 1 \mathrm{a} 5$

\begin{abstract}
ABSTRAK: Penelitian ini bertujuan untuk mengetahui tingkat kepeduliaan mahasiswa Program Studi Ilmu Perpustakaan UIN Sunan Kalijaga Yogyakarta dalam mencegah persebaran berita bohong yang berasal dari internet. Pencegahan tersebut dilakukan melalui pengidentifikasian berita bohong dengan indikator yang telah ditetapkan oleh International Federation of Library Associations (IFLA). Penelitian ini merupakan penelitian deskriptif kuantitatif dengan angket sebagai teknik pengumpulan datanya didukung oleh wawancara dan observasi nonpartisipatif pasif. Grand mean digunakan untuk menyimpulkan data dari kuesioner yang terkumpul. Hasil penelitian menunjukkan bahwa kepedulian mahasiswa Ilmu Perpustakaan UIN Sunan Kalijaga termasuk dalam kategori tinggi, dengan skor 3,77 dari rentang nilai 1 sampai dengan 5. Mahasiswa Ilmu Perpustakaan UIN Sunan Kalijaga memiliki kemauan dan kemampuan untuk mengenali berita bohong di internet, meliputi 1) kemauan untuk bertanya kepada pakar, 2) kemampuan memahami majas konteks berita, 3) kemauan untuk memeriksa sumber berita, 4) kemampuan membaca yang tersirat, 5) kemauan menghidari prasangka (bersikap netral), 6) kemauan memeriksa waktu (tanggal) produksi berita, 7) kemauan memeriksa penulis berita, dan 8) kemauan memeriksa sumber pendukung produksi berita. Mahasiswa harus dapat berpikir kritis sebagai keterampilan utama mengidentifikasi berita bohong. Pendidikan literasi informasi dapat digunakan sebagai cara mengasah keterampilan berpikir kritis mereka.
\end{abstract}

Kata kunci: Berita bohong; literasi media; media sosial; literasi informasi

ABSTRACT: This study aims to determine the level of the Library Science student's awareness in UIN Sunan Kalijaga Yogyakarta to prevent spreading fake news from the internet. This was carried out by identifying fake news with indicators by the International Federation of Library Associations (IFLA). This research is a quantitative descriptive study. The data were obtained through questionnaires, interviews, and non-participative observation. The grand mean was used to conclude the data from the collected questionnaires. The results showed that the students' awareness of fake news was included in the high category, with a score of 3.77 from grades 1 to 5. Students of Library Science at UIN Sunan Kalijaga had the willingness and ability to recognize hoaxes on the internet, including 1) willingness to ask experts, 2) ability to understand news contexts, 3) willingness to check the sources of the news, 4) ability to read between the lines, 5) willingness to avoid prejudice (being neutral), 6) willingness to check the news production time (date), 7 ) willingness to examine news writers, and 8) willingness to examine supporting sources for news production. Students should implement critical thinking as the main skill for identifying fake news. Information literacy education can be used as a way to get their critical thinking skills.

Keywords: Fake news; media literacy; social media; information literacy 


\section{INTRODUCTION}

Fake news or hoax is a common phenomenon in Indonesia, in particular in the internet space (Aulia, 2018; Suyanto et al., 2018). The term hoax is not a new term. This term began to surface after the 2016 United States election. Hoax is generally defined as fake news that has been adapted both in appearance and feels like actual news (Jr et al., 2018). Online media has become a convenient tool for spreading hoaxes. The production of fake news is carried out by a small group of people. However, it was trusted by the public, when fake news is covered by the mainstream media (Tsfati et al., 2020). Online media can be accessed when the internet is available. Based on data from the Indonesian Internet Service Providers Association (APJII) that internet users in Indonesia in 2019-2020 have reached 73.7 percent or 196.7 million people of the total population of Indonesia (Kominfo, 2020). From the report, it is known that social media users in Indonesia are quite large, such as Facebook with 71.6 million, Instagram with 19.9 million, and Youtube with 14.5 million (Kemp, 2020). In connection with the spread of hoaxes, 800 hoax spreading sites were detected in Indonesia (Kominfo, 2017). This allows Indonesian people to easily get fake news.

A large number of social media users in Indonesia is a challenge, especially once dealing with access to information (Setiawan, 2018). People who do not have adequate literacy competence will find it difficult to identify hoaxes (Abyan, 2020; Fernandes et al., 2019; Gumilar, 2017). Based on this reality, promoting awareness to read is very necessary to do. Reading is an important key to help someone identify news that is worthy of trust or vice versa (Istiarni \& Triningsih, 2018). The United Nations Educational, Scientific and Cultural Organization (UNESCO) has conducted many studies on reading interest stated that Indonesian people's reading interest in 2012 only reached 0.001 percent of 250 thousand of 250 million (Kasiyun, 2015). More recently, in 2016 World's Most Literate Nations, Central Connecticut State University published information literacy for the Indonesian people, which was ranked 60th out of 61 countries (Nopilda \& Kristiawan, 2018). This is an irony when compared to the development of smartphone subscribers that continues to increase every year (Gifary, 2015; Karuniawan \& Cahyanti, 2013).

The rapid advancement of technology that facilitates access and exchange of information needs to be supervised (Fatmawati, 2020). In the era of hoaxes that are easily spread and the rise of post-truth, the role of information agents such as librarians is urgent (Gumilar, 2017). Librarians are professionals in the field of information ideally must have good competence in identifying information, either print or information on social media/internet (T. T. Prabowo \& Manabat, 2018). Therefore, a librarian must have digital literacy skills to carry out this difficult task (Wahyudi, 2017). The key role of librarians in today's information era makes librarian education need to be taken seriously. It is an effort to strengthen the competence of librarian candidates since they were learners. In this case, formal librarian education is one of the foundations for shaping the character, knowledge, and competence of prospective librarians. In Indonesia, currently, there are about 32 universities that offered Library Science programs, ranging from diploma and undergraduate programs (Nashihuddin, 2014). The students from these universities are projected to become prospective librarians in the future.

One of the oldest library education programs in Indonesia is the Library Science Department in UIN Sunan Kalijaga Yogyakarta that was opened in 1998 and was supervised by the State Islamic Religious University (PTKIN) (Masruri, 2020). It is the only Library Science study program located in Yogyakarta offering undergraduate, master, and Ph.D. programs. There are several problems faced by undergraduate library science students, especially when accessing the rapid development of information, and more specifically, when selecting and sorting out relevant and correct news at the current days as noted by Muslichatun et al. (2019) that younger generation is said to have fallen into fake news because they focus more on the content of the news and tend to ignore the source of the news. 


\section{PREVIOUS FINDINGS}

\section{The Age of Social Media and the Spread of Hoaxes}

Social media is a means of communication that almost everyone uses these days. Facebook is one of them and has 2.07 billion active users in the third quarter of 2017. With such a large number of users, social media have certainly significant implications in human life (Prabowo, 2020). Facebook is a manifestation of the emergence of virtual communities in Howard Rheingold's terms. People tend not to meet but can chat through virtual chat rooms, access, discuss, share, and even express feelings or emotions with just a screen and a touch (quoted from Jan. A. G. M van Dijk). The next generation of social media that represents a virtual community is WhatsApps. It can be seen not only from the number of users, but also by the various features that are complete, inexpensive, and easily accessible, making WhatsApps be the choice of public communication (Ilahi, 2019). The reality is that social media (especially Facebook and WhatsApp) not only provides convenience in interacting but also might have bad effects in the form of abuse. Director of EJN Aidan White conveyed this concern about the existence of Facebook. According to him, the social media platform has become a circulation space for twisting news to hoaxes or false information (Syuhada, 2018).

The term hoax was introduced by MacDougall for the first time in his book Hoaxes in 1958. The phenomenon of hoax (which is an indicator of the post-truth era) on a global scale was evident in the 2016 succession of President of the United States of America which surprisingly won Donald Trump (Syuhada, 2018). Meanwhile in Indonesia, the term hoax emerged along with the political momentum, namely the 2014 Presidential Election and the 2017 Jakarta Regional Election (Utami, 2019). Hoax is defined as a deliberate attempt to make falsehood to cover up the truth (Utami, 2019). Michael Peters calls it the power of lie, which is a strategy to attract emotions and irrational tendencies from people (Peters et al., 2018). Hoaxes are quite worrying because they often come from unclear sources but are often repeated, reproduced, and disseminated. As a result, people are often trapped in their judgment that what they receive is valid information. Such a phenomenon is a form of hyper-reality, namely an exaggerated reality that Baudrillard has conveyed before the term hoax is as popular as it is now (Kristi, 2017). In hyper-reality, it is difficult to distinguish what is real and what is not, or to clarify because information is piled up and reproduced over and over again so that the source is not identified (Ritzer, 2010).

The rise of hoaxes requires individuals to be more careful in assessing information. In this digital era, hoaxes are very easy to produce, especially through social media when compared to other media because of three things; 1) social media provide freedom for anyone to access them without complicated restrictions/rules like real people, 2) Mainstream media such as television is more controlled by people or groups who have political tendencies thus eliminating neutrality and public trust, and 3) the massive use of gadgets so that it is correlated with the increasing number of social media users and the emergence of hoaxes (Istriyani \& Widiana, 2017). The spread of hoaxes shows that the use of media is very dependent on its users. Media and Information Literacy (MIL) refers to "essential competencies (knowledge, skills, and attitudes) that enable citizens to engage with the media and other information providers effectively, and develop critical thinking and lifelong learning skills to socialize and become good and active citizens" (UNESCO, 2012). On the other hand, IFLA has made simple steps to identify the truth of a story. The IFLA article entitled "How to Spot Fake News" (IFLA, 2019), explained that there are eight simple steps to find out the truth of the news.

According to IFLA, to be able to identify the original or fake news, netizens can do the following things: First, checking news sources. Netizens can open the news presenter's site. This is done to identify more deeply who is the maker or creator of the information. Second, checking out news writers. This is done to determine the credibility of the author. Through the knowledge of news writers, it can help netizens to believe or not the news that is conveyed. Third, check the publication date of the news. Netizens can ensure that news is read, uploaded at the time it is 
received. This indicates that the news has just been received, not the result of reposting old news. Outdated news, may not be relevant to current events. Fourth, avoiding prejudice. When reading news, netizens must be neutral people, so that they do not affect perceptions or judgments in reading news. Fifth, scanning news content. Netizens should read the content of the news between the lines. Avoid just reading the title and immediately giving an assessment. The title of a news story can be given in a bombastic way to attract readers. In this case, it is very important to read the whole news. Sixth, checking support sources. Any news that is spread should be supported with other related documents. These supporting documents usually come from other sites that present the same news. To avoid fake news, netizens can check any supporting news that is included in the headlines. Seventh, identifying the type of news. This identification is intended to find out whether the news received is fake or indeed valid. If there are discrepancies in the news received, netizens can question it and do not easily believe it. Eight, asking the experts. This is done when netizens are no longer able to identify news independently. Netizens can confirm the truth of the news to the information center, for example, librarians or secretariat where the news is published. follows;

In addition, there are other ways to identify the truth of news (Stein-Smith, 2017), as

a. Checking news that looks correct with other sources of information to see if it is from a trusted source.

b. Need to check with trusted news sources if a story seems untrustworthy and seems scary.

c. If the news is based on surveys, statistics or polls, it is necessary to check the source to see the relevance and reliability of the data.

d. Click "about us" or "who we are" to get more information about the source and authors on a website.

e. Check URLs. Sometimes URLs are disguised using uppercase, lowercase, or spelling disguised. A different URL will take the reader to another source of potentially hoax information.

f. Looking for news from various sources.

\section{Longlife Education: Countering Hoaxes}

Hoaxes are a challenge for the technological society of the current era. Hoaxes can be in the form of fake news and/or disinformation (McDougall et al., 2019). The spread of hoaxes is increasingly being driven by the widespread use of the internet as a means of communication, called social media. Social media can be used easily for spreading hoaxes. Social media as a form of digital citizens has increased the speed of citizens' mobility and has positive and negative impacts (Saputra \& Al Siddiq, 2020). Social media can be used as a medium for the integration of formal and informal learning through a personal learning environment approach (Dabbagh \& Kitsantas, 2012). One of the negative impacts is the production of untrue news as hate speech or the like. Fake news is produced with the help of artificial intelligence technology, for example, deepfake that is harder to detect (Nazar \& Bustam, 2020). Hence, it makes community participation is important to carry out joint prevention efforts from the spread of fake news.

Prevention of the spreading of fake news can be done online and offline. In Indonesia, there is the Anti-Defamation, Incitement and Hoax Forum (FAFHH) which is a social movement to prevent fake news by netizens. The forum participates in preventing hoaxes by doing digital scoping and counter-narrative (Jumrana et al., 2020). Digital scoping is done by reporting hoaxes that are spread on social media. Counter-narratives are carried out by checking facts and disseminating the results of the refusal.

Thus, awareness is needed to confirm every information consumed. The confirmation process is carried out by examining the information through carefully reading every sentence contained in the news. From an ideological perspective, lifelong education will enable a person to develop his potential according to his life needs (Hasbullah, 2017). In the process, someone needs confirmation to identify which ones are hoaxes and which are not. The continuous process of acquiring new knowledge is the principle of long-life education. The concept of lifelong 
education, defined as a formal goal or idea for organizing and structuring educational experiences (Hasbullah, 2017). In this case, news that is not yet clear is processed by re-reading it carefully, tracing sources based on previous experiences so that there is a process of acquiring knowledge about the truth of the information received. Therefore, digital literacy is closely related to humans in the digital era (Saputra \& Al Siddiq, 2020).

In long-life education, a person must have an awareness that he is a lifelong learner. People who stop learning like the blood flow in their body has frozen so that the circulation of knowledge has also frozen. Information literacy and technology are needed to ensure the security of information circulating in the community. Factors that affect information security awareness include self-awareness, cultural beliefs and assumptions, and social conditions (Rezgui \& Marks, 2008). People who are aware of themselves as lifelong learners, seem to learn as a logical way to solve problems and are highly motivated to learn at all ages and accept lifelong challenges and changes as providing opportunities to learn new things (Hasbullah, 2017).

Several motivating factors for humans to always learn (lifelong education) include (a) advances in science and technology, (b) increasingly diverse sources of information, (c) technology-based work tools, and (d) rapid social change. The more advanced a society, the more diverse the sources of life. The development of Science and Technology (IPTEK) requires every human being to adapt. Learning as a person's embodiment in adapting to environmental changes. The more advanced a society is, the more demanding people are to have adequate knowledge, including the knowledge of identifying fake news (hoax).

\section{RESEARCH METHODOLOGY}

This quantitative descriptive research determines the level of student care about the spread of fake news and describes the information literacy abilities of the respondents. The population was students of the Library Science study program at UIN Sunan Kalijaga Yogyakarta. The students of the Library Science study program were chosen because the profile of the graduates of this study program is librarians who are closely related to information processing activities. A sample of 34 students, selected through purposive sampling, are currently taking a thesis because it is considered a sample that has obtained sufficient knowledge from lecture results to identify hoaxes. The data were obtained by distributing questionnaires, non-participatory observations, and interviews. The questionnaire was submitted online using the Google Form instrument. The non-participatory observation was carried out by observing the actions of students when they received news from their gadgets. Interviews were conducted to directly validate the respondents regarding the answers they had given in the questionnaire. Only 30 out of 34 respondents were involved in observing and confirming the interview activities.

In this study, it was sought about student concern for the flow of information that existed in their lives. The concern of students with the flow of information in question is their willingness to implement the stages in identifying fake news through the eight stages of the International Federation of Library Associations. Their level of concern can lead to the level of information literacy skills possessed by each respondent. The data were measured by using the Likert Scale (scale 1-5). To find the scale range of respondents' answers using the formula:

$$
\begin{aligned}
& R S=\frac{m-n}{b} \\
& \text { where: } \\
& \quad \mathrm{RS}=\text { Scale Range } \\
& \quad \mathrm{m}=\text { Highest score } \\
& \mathrm{n}=\text { Lowest score } \\
& \mathrm{b}=\text { Scoring scale (Simamora, 2008). }
\end{aligned}
$$


The calculation of the scale range is as follows:

$$
\begin{aligned}
& \mathrm{RS}=\frac{5-1}{5} \\
& \mathrm{RS}=0,80
\end{aligned}
$$

With a scale range of 0.80 then a rating scale is made as follows:

$$
\begin{aligned}
& 1,00-1,80=\text { Very low } \\
& 1,80-2,60=\text { Low } \\
& 2,60-3,40=\text { Medium } \\
& 3,40-4,20=\text { High } \\
& 4,20-5,00=\text { Very high }
\end{aligned}
$$

\section{RESULTS AND FINDINGS}

As academicians, undergraduate students can at least help reduce and prevent the spread of fake news, to think critically and analytically in receiving information. They must be able to more conscious to achieve true happiness by fortifying themselves from fake information. Based on IFLA (The International Federation of Library Associations and Institutions) reports, it has three categories of identifying fake news; reading, checking, and clarifying news.

\section{Read News Content}

Reading is categorized as the underlying step of the three categories of identification of fake news (IFLA, 2019). It is explained that the title of certain news is sometimes interesting, but the content does not necessarily provide the correct information. Impressed titles are used by newsmakers to attract audiences to read and distribute information into the news. However, there is no guarantee of the validity of the information in the news. Hence, a wise reader must be able to identify the validity of information and not distribute it in hurry. Identification of fake news is checking the contents of articles with rhapsodic titles and reading all parts of the article before concluded. Having critical thinking skills is a key skill in media and information literacy (IFLA, 2019). One of the missions of the library is to educate and advocate for its interests (IFLA, 2019). Reading is the beginning of students being able to identify fake news.

First, check the content of articles with impressive titles. Based on the survey, it shows that most students more often read articles with impressive titles before distributing them. People will be more interested in reading articles with rhapsodic or enthusiastic titles. However, some impressive titles in news do not match the content. If the content is not as great as the title, there will be feelings of disappointment after reading or even stopping reading the article. Second, reading the entire article before concluded. This step starting from filtering the title, content, to the source of the information. News content needs to be understood in depth through careful reading with clarity of mind. Based on the survey that a complete reading of the article is carried out to obtain the correct conclusion according to its contents. Understanding the entire content of the article can avoid misperception of information. Hence, students are not consumed by hoaxes by only reading the title and the information that they get incompletely. Being part of that, reading the entire article can prevent them from prejudice or misinterpretation. Most students took preventive action by trying to understand the information contained in the news so that there is no misinterpretation. Precautions, Sentanu (2017) explains that it is included in the actions of humans who have consciousness of 'AiR' (reason, senses, and taste). This consciousness flows in the human soul who has a calm heart, thinks positively, and acts carefully.

The current generation (21st century) needs to have a robust foundation once they have new friends and dealing with technological advances. They must have skills in critical and creative thinking, communication, listening, acting assertively, and finding conflict solutions (Zuchdi et al., 2015). In addition, they need to be trained in three things; working memory, 
inhibitory control, and cognitive flexibility (Kasali, 2018). Reading the news content thoroughly could be able to identify its validity, including the inhibitory control that has been carried out by the Library Science students. The habit of reading thoroughly increases students' thinking power to behave constructively and become managers of information dissemination from articles and news they receive through social media. It is found that some Library Science students aware of their personal development to be lifelong learners to improve their quality towards intellectual people according to the goals of Indonesian national education.

\section{Check the Sources, Authors, and Date}

As Howard Rheingold describes that we are faced with the reality of a virtual society that is involved in indirect relationships through the media. Such a condition, people are vulnerable to symptoms of hyperreality which obscure the real reality as stated by Baudrillard (Kristi, 2017), with the current term that is popular now that is a hoax. However, this does not mean that hoaxes cannot be anticipated. There are indicators of whether the information is a hoax or not. Based on the parameters presented by IFLA (see Figure 1), several indicators measured by students' ability to identify fake news are efforts to check the validity of the source, the clarity of the author's profile, and the time of news posted.

\section{Checking the sources}

This is manifested by the act of checking the site official, the mission, and the supporting sources or links on the site. Based on the survey that $55.9 \%$ of respondents agreed to check the sources of the news received on social media. Furthermore, $32.4 \%$ answered strongly agree. It can be interpreted that the majority of students stated that checking news sources or websites is an urgent thing to avoid fake news (hoaxes), along with efforts to cross-check supporting sources or links in the news articles, which are indicated by $41.2 \%$ agreed and $17.6 \%$ strongly agreed. Hence, checking news sources or sites and links (supporting sources) is important. However, some respondents have not been observant in examining the mission carried out by a page or news site. At least 38.2\% of respondents still expressed doubt in checking the mission carried out by a news site. The reasons given are indeed quite classic, among others is no time to think spontaneously to explore the mission carried out by online media, and searching for the author's full profile is considered a waste of time and effort.

\section{Checking author's profile}

Based on the infographic compiled by IFLA, one thing to identify the news is to check the author's profile. It can be explicitly described by trying to find the identity of the authors including their track record. This is to ensure whether the existence of the author is a real subject (non-fictional or fake person). Based on the survey, it is shown that although the majority (nearly 60\% of respondents) have tried to check the author's profile of information more than a third of them have not practiced it intensely. It was driven by reasons as follows;

1) No time to think spontaneously to check the author's profile

2) Do not understand the importance of checking the author's profile

3) Searching for the author's profile is considered a waste of time and effort

4) Tend to focus on the content of the news. Especially if the content is already considered interesting and following the reader's way of thinking.

Therefore, it can be said that some students have not responsive or have not put awareness to filter news. In the other words, they are still vulnerable to being touched by fake news.

\section{Checking News Date}

Most respondents (88.3\%) agreed and strongly agreed that checking the time when the news was posted is important. The newness of the news (posted time) has relevance to current conditions. They tend to look at the time to determine the newness of the news because what is needed is the latest news or information. Old news is considered to have expired and does not represent current conditions or events. Based on what is presented above, it can be concluded 
that the foresight of students in filtering fake news is still in minimum efforts like checking the authenticity of the media, a brief profile of the author, and the time of the news posted.

\section{Clarification of News Authenticity and Authors' Profile}

\section{Willingness to check author profile}

The advanced technology makes anyone able to produce information without any filters. For example, social media as a medium to express something can be easily and cheaply used. However, it might cause problems in the future due to the media could be misused by irresponsible persons. Fake accounts on social media growing in the general election known as buzzers. Authentication is a necessity to minimize the spread of fake news through fake writers.

Based on the survey, it can be seen that there are still 5.9\% of respondents who answered strongly disagree and $2.9 \%$ of respondents answered that they did not agree to check the author's profile. They thought that it would be better to check if it was done by looking for information from other sources so that later they would find out whether the trusted news and the fake ones. In addition, some news on the internet has not mentioned its writer's profile, thus making the readers have to work extra to find out who wrote the article. In the study, $32.4 \%$ of respondents were lack to check the author's profile. This attitude is almost not much different from those who take a disapproving attitude because several respondents admitted that as long as they believe that the news is true, it does not matter who wrote it. This later became popular with the term post-truth, which means to assume the truth based on personal assumptions before any proof. However, Library Science students cannot be said to be careless in searching for the right information. Most of them behave to check the author's profile before believing and spreading the news. The respondents who take this attitude are very concerned about the authentication of information on the internet. They will not easily believe in the news that is not clear who the author is. Even more than that they want information written by people in the field.

\section{Prejudice in reading news}

Fake news has the potential to be more easily spread if the readers carry their feelings, especially prejudices when reviewing a news story. Based on the study, it is known that $2.9 \%$ of respondents strongly disagree to avoid prejudice. Meanwhile, $38.2 \%$ of respondents are hesitant to use or not their prejudices. This prejudice is almost unavoidable because usually news is very closely related to the author's personal opinion without any research. If the article is read by people who are looking for news just to strengthen their personal opinion, the chances of fake news being spread will be even greater. Some respondents even think that prejudice is a form of caution in receiving the news. However, that does not mean that all library science students involve prejudice rather than common sense, this is stated by $23.5 \%$ of respondents and $20.6 \%$ of respondents who strongly agree not to involve prejudice too much when reading the news. They want authentic information based on facts without any tendencies, including prejudice.

\section{Willingness to ask experts}

There are about $58.9 \%$ of respondents want information on the internet to be written by experts in their fields. Nevertheless, there are a few respondents who did not agree that asking the experts is $2.9 \%$. They will only do this if the theme is very interesting to them, thus for readings that respondents think are less interesting. Certainly, this clarification activity to experts does not need to be carried out. Although the rate for this activity is quite low, there are $20.6 \%$ of respondents are hesitant to do this because they have difficulties directly meet experts in certain fields. Meanwhile, related to "author's profile" before, there are still quite a lot of respondents who tend to be lazy to just check the author's profile on the site they are reading. This phenomenon can be understood when checking online only needs to move a lazy finger, especially to check offline which requires more effort.

This situation is understandable because it is currently so difficult to find the validity of news. Even so, most respondents still carry out this clarification activity. It can be seen from 
$26.5 \%$ of them agreed and $50 \%$ of respondents answered strongly agree to clarify with the experts. Fake news that is spread on the internet is very damaging, so asking experts can be an alternative to stop them all from spreading in cyberspace. The respondents clarify to the experts, especially when they are doing research or other academic tasks.

\section{CONCLUSION}

Information is one of the important things in society. Information may come from various sources, both electronic and non-electronic. In the current era, information flowed so fast through the internet. Therefore, every person is necessary to be skilled in order not to be deceived by fake news through indicators released by the International Federation of Library Association (IFLA) which consist of eight indicators. A practice 'filter before sharing' can be done by organizing literacy education or information literacy skills mentioned by Ravenscroft et al., (2012). Media literacy education can be used as a way for library science students to improve their literacy skills (Johnston, 2020). In addition, information literacy education and content management can also be used to support students' information literacy skills (Auberry, 2018).

Based on the study, students of the Library Science study program in UIN Sunan Kalijaga Yogyakarta had a high concern in preventing the spread of hoaxes by identifying the truth of the news, with a score of 3.77 from a score range of 1 to 5 . Out of 8 (eight) IFLA indicators, it can be seen that each score is as follows; (a) checking the source (3.76 = high), (b) checking the author's profile $(3.45=\mathrm{high}),(\mathrm{c})$ checking the time $(4.24=$ very high $),(\mathrm{d})$ avoiding prejudice $(3.82=$ hight), (e) reading implicitly ( $3.41=$ high), (f) checking the supporting sources $(3.56=$ high), $(\mathrm{g})$ what is the joke $(3.68=$ high $)$, and $(\mathrm{h})$ asking the expert ( $4.24=$ very high).

\section{REFERENCES}

Abyan, G. S. (2020). Strategi Literasi Media Mahasantri Gontor 2 Dalam Mencegah Isu Hoax. Sahafa Journal of Islamic Communication, 2(2). https://doi.org/10.21111/sjic.v2i2.4138

Auberry, K. (2018). Increasing students' ability to identify fake news through information literacy education and content management systems. The Reference Librarian, 59(4), 179-187. https://doi.org/10.1080/02763877.2018.1489935

Aulia, D. P. (2018). Memerangi Berita Bohong Di Media Sosial (Studi Terhadap Gerakan Masyarakat Anti Fitnah Indonesia). Skripsi. http://repository.uinjkt.ac.id/dspace/handle/123456789/41108

Dabbagh, N., \& Kitsantas, A. (2012). Personal Learning Environments, social media, and selfregulated learning: A natural formula for connecting formal and informal learning. The Internet and Higher Education, 15(1), 3-8. https://doi.org/10.1016/j.iheduc.2011.06.002

Fatmawati, E. (2020). Tantangan Literasi Informasi Bagi Generasi Muda Pada Era Post-Truth. Jurnal Perpustakaan Pertanian, 28(2), 57-66. https://doi.org/10.21082/jpp.v28n2.2019.p57-66

Fernandes, R., Putra, E. V., \& Muspita, R. (2019). Optimalisasi Institusi Pendidikan Sebagai Upaya Pengendalian Hoax. Jurnal Pengabdian Dan Pemberdayaan Masyarakat, 1(1). https://doi.org/10.24036/abdi/vol1-iss1/2

Gifary, S. (2015). INTENSITAS PENGGUNAAN SMARTPHONE DAN PERILAKU KOMUNIKASI (Studi Pada Pengguna Smartphone di Kalangan Mahasiswa Program Studi Ilmu Komunikasi Universitas Telkom). Jurnal Sosioteknologi, 14(2), Article 2. https://doi.org/10.5614/sostek.itbj.2015.14.2.7

Gumilar, G. (2017). LITERASI MEDIA: CERDAS MENGGUNAKAN MEDIA SOSIAL DALAM MENANGGULANGI BERITA PALSU (HOAX) OLEH SISWA SMA. Jurnal Pengabdian Kepada Masyarakat, 1(1). http://jurnal.unpad.ac.id/pkm/article/view/16275

Hasbullah, H. (2017). Dasar-Dasar Ilmu Pendidikan Edisi revisi. Rajawali Pers. 
IFLA. (2019, January 7). IFLA -- How To Spot Fake News. IFLA. https://www.ifla.org/publications/node/11174

Ilahi, H. N. (2019). Women and Hoax News Processing on WhatsApp. Jurnal Ilmu Sosial Dan Ilmu Politik, 22(2), 98-111. https://doi.org/10.22146/jsp.31865

Istiarni, A., \& Triningsih. (2018). Jejak pena pustakawan. Azyan Mitra Media.

Istriyani, R., \& Widiana, N. H. (2017). Etika Komunikasi Islam vs Hoax di Dunia Maya. Jurnal Ilmu Dakwah, 36(2).

Johnston, N. (2020). Living in the World of Fake News: High School Students' Evaluation of Information from Social Media Sites. Journal of the Australian Library and Information Association, 69(4), 430-450. https://doi.org/10.1080/24750158.2020.1821146

Jr, E. C. T., Lim, Z. W., \& Ling, R. (2018). Defining “Fake News.” Digital Journalism, 6(2), 137-153. https://doi.org/10.1080/21670811.2017.1360143

Jumrana, Partini, \& Wastutiningsih, S. P. (2020). Netizen participation in the counter narrative of the anti-hoax movement in Indonesia. International Journal of Innovation, Creativity and Change, 13(1), 569-582. Scopus.

Karuniawan, A., \& Cahyanti, I. Y. (2013). Hubungan antara Academic Stress dengan Smartphone Addiction pada Mahasiswa Pengguna Smartphone. 2(1), 6.

Kasali, R. (2018). Self Disruption. Penerbit Mizan.

Kasiyun, S. (2015). Upaya meningkatkan minat baca sebagai sarana untuk mencerdaskan bangsa. Jurnal Pena Indonesia, 1(1), 79-95. https://doi.org/10.26740/jpi.v1n1.p79-95

Kemp, S. (2020, January 30). Digital 2020: 3.8 billion people use social media [Special Report]. We Are Social. https://wearesocial.com/blog/2020/01/digital-2020-3-8-billionpeople-use-social-media

Kominfo, R. (2017, December 13). Ada 800.000 Situs Penyebar Hoax di Indonesia. Website Resmi Kementerian Komunikasi Dan Informatika RI. http:///content/detail/12008/ada800000-situs-penyebar-hoax-di-indonesia/0/sorotan_media

Kominfo, R. (2020, November 9). Dirjen PPI: Survei Penetrasi Pengguna Internet di Indonesia Bagian Penting dari Transformasi Digital. Website Resmi Kementerian Komunikasi Dan Informatika RI. http:///content/detail/30653/dirjen-ppi-survei-penetrasi-penggunainternet-di-indonesia-bagian-penting-dari-transformasi-digital/0/berita_satker

Kristi, P. (2017, February 11). Gaduh di Media. Kompas.

Masruri, A. (2020). UIN Sunan Kalijaga Yogyakarta. Sejarah Pendidikan Kepustakawanan. http://ip.uin-suka.ac.id/id/page/prodi/619-Sejarah

McDougall, J., Brites, M.-J., Couto, M.-J., \& Lucas, C. (2019). Digital literacy, fake news and education / Alfabetización digital, fake news y educación. Cultura y Educación, 31(2), 203-212. https://doi.org/10.1080/11356405.2019.1603632

Muslichatun, M., Rahmawati, N., Permatasari, W. W., \& Mahgfiroh, A. F. (2019). PEMAHAMAN MAHASISWA TERHADAP PENYEBARAN BERITA BOHONG (HOAX) DI MEDIA SOSIAL DALAM PERSPEKTIF UNDANG-UNDANG NOMOR 19 TAHUN 2016 TENTANG PERUBAHAN UU NO. 11 TAHUN 2008 TENTANG INFORMASI DAN TRANSAKSI ELEKTRONIK. LONTAR MERAH, 2(2), 179-193.

Nashihuddin, W. (2014). Perkembangan Pendidikan Ilmu Perpustakaan Indonesia: Dari Masa Ke Masa. Jurnal Pustakawan Indonesia, 13(1), Article 1. https://journal.ipb.ac.id/index.php/jpi/article/view/8771

Nazar, S., \& Bustam, M. R. (2020). Artificial Intelligence and New Level of Fake News. 879(1). Scopus. https://doi.org/10.1088/1757-899X/879/1/012006

Nopilda, L., \& Kristiawan, M. (2018). Gerakan literasi sekolah berbasis pembelajaran multiliterasi sebuah paradigma pendidikan abad ke-21. JMKSP (Jurnal Manajemen, Kepemimpinan, dan Supervisi Pendidikan), 3(2).

Peters, M. A., Rider, S., Hyvönen, M., \& Besley, T. (2018). Post-Truth, Fake News: Viral Modernity \& Higher Education. Springer.

Prabowo, T. T., \& Manabat, A. R. (2018). Libraries and the Fake News Hoopla: A Comparative Study of Selected Indonesian and Philippine Academic Libraries' Information Literacy Programs and Its Role in Countering Fake News. 7th Congress of Southeast Asian Librarians (CONSAL), Naypyitaw. 
Prabowo, Thoriq Tri. (2020). Memperebutkan Ruang Publik Virtual: Literasi, Hoax, dan Perdamaian. Zahir Publishing.

Ravenscroft, A., Lindstaedt, S., Kloos, C. D., \& Hernández-Leo, D. (Eds.). (2012). 21st Century Learning for 21st Century Skills: 7th European Conference of Technology Enhanced Learning, EC-TEL 2012, Saarbrücken, Germany, September 18-21, 2012. Proceedings (Vol. 7563). Springer Berlin Heidelberg. https://doi.org/10.1007/978-3-642-33263-0

Rezgui, Y., \& Marks, A. (2008). Information security awareness in higher education: An exploratory study. Computers \& Security, 27(7-8), 241-253. https://doi.org/10.1016/j.cose.2008.07.008

Ritzer, G. (2010). Teori Sosial Postmodern. Terjemahan Muhammad Taufik. Kreasi Wacana.

Saputra, M., \& Al Siddiq, I. H. (2020). Social media and digital citizenship: The urgency of digital literacy in the middle of a disrupted society Era. International Journal of Emerging Technologies in Learning, 15(7), 156-161. Scopus. https://doi.org/10.3991/IJET.V15I07.13239

Sentanu, E. (2017). Karakter 360. PT Elex Media Komputindo.

Setiawan, B. (2018). INDONESIA DARURAT HOAKS? Informasi, 48(2). https://doi.org/10.21831/informasi.v48i2.23210

Stein-Smith, K. (2017). Librarians, Information Literacy, and Fake News. Strategic Library, 37(14).

Suyanto, T., Prasetyo, K., Isbandono, P., Zain, I. M., Purba, I. P., \& Gamaputra, G. (2018). Persepsi mahasiswa terhadap kemunculan berita bohong di media sosial. Jurnal Civics: Media Kajian Kewarganegaraan, 15(1).

Syuhada, K. D. (2018). Etika Media di Era “Post-Truth.” Jurnal Komunikasi Indonesia, 6(1), 75-79. https://doi.org/10.7454/jki.v6i1.8789

Tsfati, Y., Boomgaarden, H. G., Strömbäck, J., Vliegenthart, R., Damstra, A., \& Lindgren, E. (2020). Causes and consequences of mainstream media dissemination of fake news: Literature review and synthesis. Annals of the International Communication Association, 44(2), 157-173. https://doi.org/10.1080/23808985.2020.1759443

Utami, P. (2019). Hoax in Modern Politics: The Meaning of Hoax in Indonesian Politics and Democracy. Jurnal Ilmu Sosial Dan Ilmu Politik, 22(2), 85-97. https://doi.org/10.22146/jsp.34614

Wahyudi, P. I. H. (2017). Pentingnya Keterampilan Digital Literasi Bagi Pustakawan. Khizanah alHikmah: Jurnal Ilmu Perpustakaan, Informasi, dan Kearsipan, 5(2), 187-195. https://doi.org/10.24252/kah.v5i2a6

Zuchdi, D., Kuntoro, S. A., Kunprasetyo, Z., \& Widayati, A. (2015). Pendidikan Karakter: Konsep Dasar dan Implementasi di Perguruan Tinggi. UNY Press. 